\title{
Różne punkty widzenia
}

Na ziemiach północno-wschodnich Drugiej Rzeczypospolitej oraz w województwie białostockim - będącym swego rodzaju łącznikiem z Polską centralną - w latach drugiej wojny światowej i tuż po niej wydarzenia historyczne miały niezwykle dramatyczny przebieg. Geneza ich po części tkwiła w sytuacji w okresie międzywojennym, bardziej jednak wynikała $\mathrm{z}$ dążeń różnych państw i narodów do opanowania tych ziem. Zwycięzca zmagań - strona radziecka - miała też przez wiele lat monopol na narzucanie tutejszemu społeczeństwu interpretacji najnowszej historii. Tymczasem, po upadku tego monopolu, okazuje się, że jego miejsce zajmuje nie tyle wersja obiektywna, co raczej wersje subiektywne - narodowe: polska, litewska, białoruska, żydowska. Przykładem tego mogą być książki Jerzego Wiesiołkowskiego ${ }^{1}$ i Tobiasza Cytrona ${ }^{2}$. Sa to, co prawda, prace o charakterze publicystyczno-wspomnieniowym, mają one jednak szerszy krąg czytelników niż wiele monografii historycznych i w znacznym stopniu przyczyniają się do kształtowania opinii o stosunkach narodowościowych na wzmiankowanym obszarze w latach ostatniej wojny światowej.

Pierwszy z nich - Jerzy Wiesiołkowski - ur. w 1924 r. w woj. nowogródzkim w rodzinie weterynarza, pod koniec niemieckiej okupacji znalazł się w Szkole Oficerskiej Białoruskiej Krajowej Obrony, formacji działającej u boku armii niemieckiej i z tą armią wycofał się na Zachód. Tam wkrótce przeszedł na drugą stronę i jako obywatel RP skierowany został do polskich formacji. Później, z przerwami, był aktywnym działaczem emigracji białoruskiej w Wielkiej Brytanii, a w latach dziewięćdziesiątych wydał 3 książki poświęcone historii najnowszej Białorusi, w tym jedną - będącą obiektem naszych zainteresowań - dotyczącą Armii Krajowej ${ }^{3}$.

Już we wstępie do niej poznajemy intencje autora: fakty przedstawione w książce mają stanowić ostrzeżenie dla tych Białorusinów, którzy myślą, że Polacy są lepsi od Rosjan. Z pracy wynika, iż sa oni nie tylko nie lepsi, ale zdecydowanie gorsi, w dodatku zadowoleni z siebie. Pod koniec konkluduje więc, żeby zainteresowali się co sądzą o nich inni, a zwłaszcza sąsiedzi. Z kolei trudno stwierdzić na ile sądy Wiesiołkowskiego o Polakach są typowe dla Białorusinów, jest jednak faktem, iż 
jego tezy - jak do tej pory - nie spotkały się z polemiką nawet ze strony historyków białoruskich w Polsce. Spróbujmy je przedstawić.

Charakteryzując sytuację w okresie międzywojennym, bardzo krytycznie ocenia stanowisko rządów RP wobec Białorusinów. Oczywiście, że polityka ta nie była dobra, ale też nie była tak skrajnie zła, jak pokazuje to Wiesiołkowski, pisząc np. o aresztowaniach za samo składanie podpisów za utworzeniem szkół białoruskich, o 300 tysiącach osadników polskich itp. W swoim krytycyzmie dochodzi nawet do tego, że lata okupacji radzieckiej (1939-1941) ocenia lepiej niż okres międzywojenny, bo - jego zdaniem - Białorusini nie mieli tego w sanacyjnej Polsce, co otrzymali wówczas Polacy, a z wejściem Armii Czerwonej na tzw. „kresy” nikt Polaków nie prześladował (s. 48). O deportacjach ludności wspomina tylko w tym kontekście, że Białorusini nie żałowali wywiezienia osadników, bo byli to obcy ludzie na ich ziemi. Polaków i ich organizacje na ziemiach wschodnich traktuje właśnie jako element zupełnie obcy. Wielokrotnie podkreśla, że Polaków było mało i w czasie wojny, aby nadać Zachodniej Białorusi polski charakter wysyłano tam spadochroniarzy pochodzących z Polski centralnej. Odrzuca też całkowicie tezę o poparciu miejscowego społeczeństwa dla Armii Krajowej, która miała być - przede wszystkim - sposobem na zachowanie polskości na kresach.

Wiesiołkowski dąży wszelkimi sposobami do dyskredytacji AK, przedstawiając ją jako organizację antybiałoruską i wręcz zbrodniczą. W wielu miejscach powtarza, że nie tylko AK paliła białoruskie wioski i likwidowała białoruską inteligencję, ale w ogóle Polacy „terroryzowali białoruską ludność" (s. 106) i „starali się wymordować jak najwięcej Białorusinów swoimi i cudzymi rękami" (s. 113). Nawet jeden z rozdziałów nosi właśnie tytuł: Swoimi i obcymi rękami AK likwidowała Białorusinów.

AK - z jednej strony - przypisuje wszystkie najgorsze cechy, z drugiej zaś wyśmiewa ją, bo organizacja, która nie potrafiła zająć jednego miasta (Wilna), chciała zagarnąć całą Zachodnią Białoruś. Jego zdaniem operacja „Ostra Brama” zakończyła się hańbą dla AK, ponieważ całe jej dowództwo NKWD aresztowało bez jednego wystrzału.

Wiesiołkowski uważa, że po wyzwoleniu zaczęły dziać się rzeczy straszniejsze niz podczas okupacji niemieckiej, gdyż wzmogły swoją działalność „bandy AK”, które prowadziły „nikczemną i beznadziejną walkę” (s. 178). Jedynym sensem kontynuacji walki przez AK - pisze dalej - był „prymitywny bandytyzm zabarwiony nienawiścią do miejscowej ludności białoruskiej" (s. 189). Niejako symbolem jest dla niego obelisk w Szczuczynie (obecnie obwód grodzieński), na którego jednym boku wypisane są nazwiska miejscowych żołnierzy poległych w czasie wojny, na drugim zaś - więcej, bo 118 nazwisk mieszkańców, którzy zginęli z rąk „band złożonych z akowców" (s. 128).

Oczywiście, konsekwencją takiej oceny działalności AK jest stosunek autora do kwestii uzyskania praw kombatanckich na Białorusi przez byłych żołnierzy AK - oburzają go już same próby czczenia pamięci tych „przestępców”, „bandytów” 
(s. 129) m.in. poprzez fundowanie tablic pamiątkowych w kościołach. Jest zdecydowanie przeciwny rehabilitacji AK na Białorusi również dlatego, iż uważa, że byłoby to równoznaczne z uznaniem granicy sprzed $1939 \mathrm{r}$.

Sam nie akceptuje nawet granic powojennych - Białostocczyznę traktuje jako część Białorusi i ma pretensje do Churchilla i Roosevelta o to, że oddali ją Polsce. Krytykuje także Stalina za przekazanie Litwie „białoruskiej Wileńszczyzny z Wilnem" oraz - na prośbę Chruszczowa - części ziem białoruskich - Ukrainie. Obecnym władzom Białorusi z Łukaszenką na czele wytyka, że milczą w tych sprawach i nie żądają od sąsiadów zwrotu „zagrabionych ziem” (s. 145).

Tak więc, w zasadzie, wszystkich sąsiadów Białorusi Wiesiołkowski traktuje nieprzychylnie, choć po przeczytaniu książki można odnieść wrażenie, że prawdziwym wrogiem jest Polska. Nic więc dziwnego, że krytycznie ocenia, lub zupełnie pomija, wszystkie działania propolskie, np. Wacława Iwanowskiego. Co więcej, twierdzi, że nadal dominuje wśród Polaków duch ekspansywny, którzy przy pomocy Kościoła katolickiego nadal polonizuja Białoruś i chca przyłączyć dawne kresy wschodnie. Polscy księża na Białorusi to - jego zdaniem - „mina z opóźnionym zapłonem” (s. 170). Zresztą wszystko co katolickie uważa za wrogie Białorusi, nawet Konstanty Kalinowski nie jest dla niego bohaterem narodowym, lecz katolickim fanatykiem nienawidzącym prawosławnych.

Wiesiołkowski, choć to emigracyjny działacz białoruski, pisze jak dawny, typowy historyk radziecki: dziwi się, że Piłsudski nie chciał od Lenina dobrych granic (s. 54), często powołuje się na antybiałoruską „Sowiecką Białoruś”, bo na jej łamach najostrzej krytykowano AK i cytaty stamtąd dobrze pasują do jego tez. W jakimś sensie jest też piewca czasów minionych, bo: wtedy i w BSRR i w Polsce AK-owcy siedzieli cicho (s. 180).

Nie ma sensu prostować wszystkich błędów zawartych w książce, takich jak np. ocena, że „cichociemni” to ideolodzy „Polski dla Polaków”, czy NSZ - to „skrajnie reakcyjna organizacja piłsudczykowska", której - choć w zasadzie nie działała ona na ziemiach wschodnich - autor poświęca sporo miejsca. Pomijając aspekt historyczny, jest to publikacja szkodliwa dla samych Białorusinów i dziwi mnie, że przynajmniej historycy białoruscy w Polsce nie odcięli się od skrajnych tez autora, lecz nabrali wody w usta. Przykładem może być wspomniana notka biograficzna poświęcona Wiesiołkowskiemu w „Białoruskich Zeszytach Historycznych” ${ }^{4}$. Co więcej, przy współudziale członków Białoruskiego Towarzystwa Historycznego wydano w Białymstoku kolejną książę tego autora ${ }^{5}$.

Tobiasz Cytron - autor pracy przedstawiającej na szerszym tle dzieje powstania w getcie białostockim - mieszka w Izraelu. Jego ojciec przed 1939 r. był prezesem gminy wyznaniowej żydowskiej w Białymstoku, on sam pracował w getcie jako lekarz, jest więc postacią obeznaną w realiach życia w tym okresie, a nie przypadkowym obserwatorem wydarzeń. Książka najpierw ukazała się w Izraelu w języku hebrajskim - Cytron napisał ją więc dla swoich rodaków. Polska wersja językowa jest efektem zachęty ze strony wymienionych we wstępie polskich historyków, zapewne 
nie znających hebrajskiego, których zainteresował temat. Publikacja ta jest bezkrytyczna gloryfikacją powstania w getcie białostockim, gloryfikacji Armii Czerwonej i partyzantki radzieckiej, błędnie nazywanej białoruską. Nie chcę oceniać kwestii szczegółowych dotyczących getta, choć nie brak informacji zaskakujących, nie potwierdzonych w źródłach i innych opracowaniach, bo nie jest to temat zupełnie dziewiczy.

Szczególne zdziwienie budzi przedstawienie stosunków narodowościowych, zwłaszcza polsko-żydowsko-niemieckich. W zasadzie autor nie pisze o pomocy udzielanej Żydom przez Polaków - co prawda jeden z żydowskich oddziałów partyzanckich dostał broń od AK, ale obdarowani dowiedzieli się przypadkiem, jakoby akowcy zamierzali ich zlikwidować i „...wystarczyło to, aby po oddziale AK nie pozostał nawet ślad" (s. 64). W książce jest za to specjalny podrozdział pt. Niemcy jako dostawcy broni dla powstańców $w$ getcie $i$ dla żydowskiej partyzantki $w$ lesie, a w nim m.in. wymienione są nazwiska przyjaznych Żydom Niemców. Czytelnik żydowski może na tej podstawie odnieść wrażenie, że jego rodacy, wspierani przez Niemców, walczyli z Polakami. Potwierdza to tytuł kolejnego podrozdziału: Walka przeciwko AK-owcom i mordercom Żydów. Najlepszą ilustracją przekonań autora będą pochodzące stamtąd krótkie cytaty: „Różnice zdań między Armią Krajową a Armią Ludową były nie do pogodzenia. I zgodnie ze starym polskim zwyczajem, kiedy dwaj Polacy się kłócą i nie mogą dojść do porozumienia - biją Żydów. I zaczęli mordować Żydów. I to na wielką skalę. W samym tylko okręgu białostockim AK-owcy zamordowali ok. 1200 Żydów” (s. 76). Zaś w końcowym okresie wojny: „W czasie gdy najlepsi synowie narodu żydowskiego walczyli z hitlerowskim wrogiem, część AK-owców, zapominając, że powinni walczyć z Niemcami - mordowała niewinnych Żydów. (...) AK-owcy szaleli wszędzie, na drogach, w pociągach. Zatrzymywali jadące pociągi, wyprowadzali z nich Żydów i strzelali do nich (...) Nie znaczy to jednak, że wszyscy Polacy byli mordercami lub popierali morderców. Byli też Polacy szlachetni..." (s. 78). I Tobiasz Cytron wymienia nazwiska kilku porządnych Polaków, jest ich jednak mniej niż Niemców.

Tych, którzy oburzają się na to, co piszą o Polakach i AK Wiesiołkowski i Cytron, odsyłam do lektury książki na temat dziejów Białegostoku w drugiej połowie 1944 roku autorstwa Polaka - Jerzego Kułaka, uważającego się za historyka ${ }^{6}$. Swój punkt widzenia określa on już we wstępie pisząc: „przedstawiam w istocie historię widzianą oczyma niemal wszystkich ówczesnych mieszkańców Białegostoku, oczywiście $\mathrm{z}$ wyłączeniem ludności pochodzenia białoruskiego i żydowskiego, która (w większości) od lat stanowiła zaplecze komunistycznej dywersji w Polsce" (s. 5). O Rosjanach, Białorusinach, a zwłaszcza Żydach, nie znajdzie się w książce dobrego słowa. Jest więc Żyd - szpicel gestapo (s. 54), Żydzi piszący antypolskie artykuły do „Rzeczypospolitej” (s. 90), Żyd z Jasionówki - kat żołnierzy podziemia (s. 37), całkowicie dominujący w białostockim UB Żydzi, Rosjanie i Białorusini - rekrutujący się z wiejskiej biedoty, „co często oznaczało po prostu wioskowego złodzieja" (s. 37). 
Charakterystyczne, że wielu autorów, choć nie tendencyjnych, raczej stara się unikać podejmowania kwestii drażliwych. Przykładem może być książka wydana przez Instytut Historii Filii Uniwersytetu Warszawskiego w Białymstoku pt. Biatostoccy Żydzi $i^{7}$. Jej część IV wypełnia obszerny artykuł Waldemara Monkiewicza $Z$ a cenę życia. O ratowaniu Żydów w Biatostockiem w okresie okupacji niemieckiej (s. 147-248). W zasadzie jest to zestawienie - głównie na podstawie materiałów Okręgowej Komisji Badania Zbrodni Przeciwko Narodowi Polskiemu w Białymstoku - kilkuset przypadków pomocy udzielonej ludności żydowskiej na tym terenie, przy czym zaledwie kilkanaście razy Monkiewicz wspomina o denuncjacji ukrywających się Żydów przez Polaków. Informując o tuz powojennych losach uratowanych, kilkakrotnie zamieszcza enigmatyczne sformułowanie „po wojnie zginą" (s. 212) lub „zginęła koło Tykocina, być może zabita przez NSZ" (s. 229). Podaje też, mniej więcej, tyle samo przypadków zamordowania rodzin polskich, które uratowały Żydów, przez bandytów szukających u nich pożydowskiego złota.

Na tym tle chciałbym zwrócić uwagę na publikację młodego historyka Zbigniewa Romaniuka, zajmującego się dziejami Brańska i okolic ${ }^{8}$. Obok opisywania przypadków pomocy i poświęcenia, przypomina on niechlubne czyny, zwyrodnienie ludzkich charakterów; wyrównywanie w czasie wojny starych porachunków - tych sprzed 1939 r. i z lat 1939-1941 - poprzez donosy do NKWD i gestapo, wyłapywanie Żydów i przekazywanie ich Niemcom za pół kilograma cukru, a także wskazywanie kryjówek Żydów przez ich rodaków. Ocenia, iż okoliczni mieszkańcy przyczynili się do śmierci około 170 brańskich Żydów (s. 10). Jednak zdecydowanie odrzuca - jak pisze - zakorzenioną w całym świecie (poza Polską), a przewijającą się także w relacjach Żydów z Brańska, tezę o „kolaboracji AK z Niemcami w celu likwidacji Żydów" (s. 10).

Opisuje również przypadki mordowania po wojnie tych, którzy przeżyli Holocaust. Jednak zauważa, że także Polacy byli wówczas narażeni na grabieże i represje ze strony wojsk radzieckich, UB, rywalizującego ze sobą podziemia oraz zwykłych grup bandyckich, w tym złożonych z byłych żołnierzy konspiracji.

Walczący ze stereotypami w przedstawianiu stosunków polsko-żydowskich nie ustrzegł się jednak potknięć przy przedstawianiu relacji polsko-białoruskich. Pisząc o furmanach zamordowanych 31 stycznia 1946 r. w Puchałach przez polskie podziemie (s. 23), nie określa ich narodowości ani wyznania, a przecież była to grupa wyselekcjonowana według tych kryteriów, na co zwracaja uwagę historycy białoruscy.

Przedstawiłem opinie pięciu autorów trzech narodowości, którzy prezentują pięć różnych punktów widzenia.

Jan Jerzy Milewski 


\section{PRZYPISY}

1. Jury Wiesjałkowski, Szto prywjało Armiju Krajowu na Biełaruś, London 1995, s. 191.

2. Tobiasz Cytron, Dzieje zbrojnego powstania w Getcie Bialostockim, Tel Awiw 1996, s. 106.

3. Antoni Mironowicz, Jerzy Wiesiołkowski (Jury Wiesjałkowski), „Białoruskie Zeszyty Historyczne" 1996, z. 2(6), s. 165-167.

4. Tamże.

5. Jury Wiesjałkowski, Biełaruś u Pierszaj Suświetnaj wajnie, Biełastok-Liondan 1996, s. 361.

6. Jerzy Kułak, Pierwszy rok sowieckiej okupacji. Białystok 1944-1945, Białystok 1996, s. 233.

7. Bialostoccy $\dot{Z} y d z i$, t. II, pod red. Adama Dobrońskiego i Waldemara Monkiewicza, Białystok 1997, s. 248.

8. Zbigniew Romaniuk, Brańsk i okolice w latach 1939-1953. Reminiscencje zdarzeń, „Ziemia Brańska", t. VI, Brańsk 1995, s. 3-38. 